\title{
Value of PET-CT in plasma cell dyscrasias: a literature and pictorial review
}

\author{
R Aggarwal', Y Griffin \\ From International Cancer Imaging Society Meeting and 15th Annual Teaching Course (ICIS 2015) \\ London, UK. 5-7 October 2015
}

\section{Learning objectives}

- To evaluate indications for PET-CT in plasma cell dyscrasias and its added value over other imaging modalities with review of literature based evidence and reference to the RCR/RCP guidelines.

- To discuss the use of PET-CT and subsequent clinical impact at our institution with pictorial illustration.

- To discuss the limitations and potential pitfalls of PET-CT with pictorial illustration.

\section{Content organisation}

- Role of imaging in the diagnosis, management and follow up of plasma cell dyscrasias.

- Indications for PET-CT and circumstances in which it is and is not likely to be beneficial with review of literature based evidence and RCR/RCP guidelines.

- Use of PET-CT at our institution with subsequent clinical impact in staging of non-secretory disease, myeloma, POEMS disease, assessing plasmacytoma response to treatment and MGUS transformation to myeloma with pictorial illustration.

- Limitations and potential pitfalls of PET-CT with pictorial illustration.

\section{Conclusion}

Although PET-CT is recommended by Durie-Salmon Plus, it is not widely adopted. RCR guidelines advise PET$\mathrm{CT}$ for monitoring non secretory myeloma and assessing active disease. At our institution, PET-CT influenced patient management in $95 \%$. PET-CT is useful in staging myeloma, in detection of occult bone/nodal disease and in detecting residual active disease or recurrent disease post chemoradiotherapy/bone marrow transplant. It is of less value in diffuse bone marrow involvement. PET-CT has

* Correspondence: reena.aggarwal@doctors.org.uk

Leicester Royal Infirmary, Infirmary Square, Leicester, LE1 5WW, UK added value to conventional imaging techniques especially when they are normal, indeterminate or contraindicated.

Published: 2 October 2015

doi:10.1186/1470-7330-15-S1-P11

Cite this article as: Aggarwal and Griffin: Value of PET-CT in plasma cell dyscrasias: a literature and pictorial review. Cancer Imaging 201515 (Suppl 1):P11.
Submit your next manuscript to BioMed Central and take full advantage of:

- Convenient online submission

- Thorough peer review

- No space constraints or color figure charges

- Immediate publication on acceptance

- Inclusion in PubMed, CAS, Scopus and Google Scholar

- Research which is freely available for redistribution
() Biomed Central

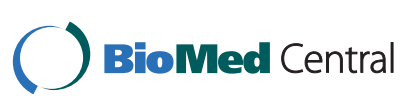

